DOI https://doi.org/10.36059/978-966-397-116-2 /2-24

\title{
PRECONDITIONS OF SUBJECTIVE RIGHTS PROTECTION IN NATIONAL ADMINISTRATIVE LEGAL PROCEEDING
}

\section{Bevzenko V. M.}

\section{From the History of National Administrative Legal Thought}

Complicated political-state and public events having taken place at the beginning of $20^{\text {th }}$ century at the Ukrainian territories, left behind terrible outcomes and changed national system of law for a long time, defining the purpose of legal science and legislation as well as their content in a fundamentally different way as it was accepted in a civilized world.

It should be recognized that a unified European-wide legal space where Ukrainian science, legislation and legal practice were created, stopped it existence after Soviet power regime establishment at the Eastern-European territories. At least for the next 70 years in USSR the party ideology, absolute and total subordination of all society members to the administrative orders of Bolshevik party and the state mechanism established by them were dominant rather than rights and freedoms of a person as well as the supremacy of law. Progressive teachings about legitimacy of law and legal acts, relations between the person and the state, its authorities, were absolutely put aside and undeservedly forgotten. Legal acts and their drafts, prepared at the beginning of Ukrainian statehood formation in the $20^{\text {th }}$ century, were either lost or fundamentally refused by a new power.

As a result, the Ukrainian administrative legal thought was regressive, with a few decades of delay in the development, comparing to the administrative law of Germany, France, the United States of America and many other civilized states of the world with perfect democracy and the law system.

The long-term oblivion experienced by the national legal thought turned out to be too big challenge for it, and the outcomes were so severe that only now scientists are beginning to find invaluable treasures of Ukrainian legal science and legislation, having not only historical, but 
also practical value. After all, they can be used to approve new and to improve existing normative acts of modern Ukraine.

However sad and even dangerous it might be, the Soviet distorted perception of administrative law, its purpose and content has continued to expand already in the modern Ukrainian legal community. Quite unsuitable for use, and even more for development, the old traditions of the era of administrative law decline distort the objective perception of administrative-legal categories, their interpretation and application.

In particular, among the administrative-legal problems that administrative courts are now trying to overcome - the definition of the content and criteria of administrative jurisdiction, its differentiation from other court jurisdictions, the grounds and limits of interference of administrative courts in the administrative discretion of public administration subjects, the definition of administrative agreement and their differentiation from the rest of private-contractual instruments of the activity of the public administration subjects, the grounds and justification of the evaluation of administrative acts in the administrative the courts and their correlation with other instruments of public administration, as well as with other documents of a legal nature.

However, more than ever in time, not only the reinterpretation of the fundamental concepts and categories of administrative law but new tasks have arisen in the front of national law science and legislation, objectively resulted from social and state progress. First of all, the need to justify and resolve new public relations has appeared.

So, we can say about continuity and rapid pace of the development of administrative-legal relations, the renewal of principles for the public authorities' activities.

For example, in administrative law contractual and service institutions, the existence of administrative-legal relations between private persons, without participation of public administration has been recognized; the instruments of administrative-legal dispute resolution by mediation are being developed; the development of studying about public property is prospective and urgent.

It should be kept in mind that the European Union law and procedure influence the national administrative law and procedure, the European administrative space at the same time continually is expanding on national administrative law and procedure of Ukraine. Until recently unknown or 
forgotten branches of administrative law are rapidly forming and developing: administrative and commercial law, municipal law, police law, public service law, and town planning law, telecommunications law, atomic law, environmental law, and many others.

Having declared the focus of public-state ideology on, in particular, a new understanding of the purpose and content of administrative law, the Ukrainian scientific community of law will have to propose a new model of teaching administrative law, its practical realization and legislative implementation.

In many aspects, the works of scientists who, despite the artificial ideological divisions of people and states, being within a single administrative-legal space, continued to develop the classical science of administrative law, preserving and multiplying its best traditions, could have played the decisive role in the final formation of a new teaching of national administrative law.

Many glorious descendants of the Ukrainian land, even under difficult living conditions and far beyond the borders of the Motherland, continued the persistent scientific research, teaching and public activities in the field of law. Among the prominent legal scholars of Ukrainian origin who devoted themselves to the study of administrative law and procedure essence - the world's best known and unknown in Ukraine Yuri Lukich Paneyko. His works, the opinions expressed in them, and the provided scientific surveys corresponded to the general ideological orientation of the European countries' administrative law, in particular Germany, Poland, France, in the context of his best achievements. It is easy to be sure in the progressive nature of scientific achievements presented in Yuri Paneyko's works, if comparing them with the modern Common administrative law of Germany.

It is also clear that although in the 20 years of the 20th century, the liberation state competition for independent Ukraine tragically ceased, but scientific and legislative work on the development and implementation of the administrative justice national institution continued. Almost at the same time, with the establishment of Soviet power at the Ukrainian territory, active law-making work continued abroad.

After the Ukrainian state decline in the 20s of the last century, the most important centers of Ukrainian emigration (representatives of the government and the army, politicians and culture) were Prague, Warsaw, 
Vienna, Berlin, and Paris. Many Ukrainians from the Naddniprianshyna were in Poland, Czechoslovakia, Romania, Yugoslavia, Bulgaria, Italy, and Belgium.

The destiny of Ukrainian emigrants was hard, they experienced numerous challenges in their life, and the activity of representatives of socio-political layers manifested in different ways and had different results. The Ukrainian emigration's activity resulted in documents and books that were stored in the State Scientific Archival Library of Kyiv. The draft law "On Courts of Administrative Cases" of the Ukrainian People's Republic of 1932 was among the documents, first discovered in 2004.

The result of the next search was the discovery of the draft of Administrative Code of the Ukrainian People's Republic of 1932 in June 2013 and the draft of Provisional Judicial system of the Ukrainian People's Republic of 1931 prepared by representatives of the Ukrainian Diaspora in the 20-30s of the 20th century. These drafts concern the field of administrative law and the judicial system, published in the form of notebooks (collections), named in accordance with their content "Draft ..." and "Motives to the draft ...".

It is interesting that three documents together - the Draft of Administrative Code of the Ukrainian People's Republic of 1932, the Draft of Provisional Judicial System of the Ukrainian People's Republic of 1931, the Draft Law on Courts in Administrative cases in the UPR of 1932 - form a peculiar, complete "set" of acts combining with each other, exhaustively regulates and protects the relations between a person and public authority.

The Draft of Administrative Code of the Ukrainian People's Republic contained a description of the rules of human behavior and subjects of public administration (settled administrative-legal relations between them).

The Draft of Provisional Judicial system of the UPR established the system and the internal structure of republic courts, which should protect public rights and verify the legality of exercise of the public administration subjects' powers executed in accordance with the Administrative Code. According to the Law on Courts in Administrative Cases, legal proceedings should be exercised concerning a person's claim against a representative of public authority. 
The Administrative Code of the UPR of 1932 contained elements of modern administrative law and legislation. As a matter of fact, this Code is one of the first in the world and national legal history procedural act, which describes the relationship between a person and public administration subjects.

The law on courts in administrative cases was nothing else but a perfect at that time, procedural code, which described the sequence and peculiarities of the implementation of administrative legal proceedings. The ideology of this Law, its content, peculiarities of the norm presentation, institutions, and stages are very similar to the content of the Code of Administrative Legal Proceedings of Ukraine in 2005, 2017.

Thus, in the 20-30s of the 20th century, Ukrainian people, in addition to one of the world's first constitutions and the Administrative Code, had a complete Code of Legal Proceedings in administrative cases.

The Provisional Judicial System of the UPR provided that a judicial system was built based on the principles of hierarchy, specialization and territoriality; common courts had to start working (considered civil and criminal cases), social courts ("Courts of Labor").

On can definitely state that these documents describe a complete and self-sufficient mechanism for the implementation and protection of public human rights in relations with the subjects of public administration. We believe that these documents were a successful practical implementation of progressive ideas and provisions of the science of administrative (police) law and administrative procedure of that time. Unfortunately, some provisions of these progressive documents was not only implemented, but were absolutely refused in Soviet Ukraine and undeservedly forgotten.

Using these documents as the examples made by the UPR representatives, we can observe a natural, logical and so necessary combination of three branches of legal activity for the society and the state, namely, research, law-making and law enforcement.

After all, unlike democratic Ukraine, the full implementation and realization of legal activity in the Soviet Ukraine, in particular, in the field of administrative law and procedure did not take place ... On the pages of documents, an ideological purpose is revealed, showing the intentions of the UPR representatives in exile: "With the end of Russian occupation the issue of implementation of the legal system in the state and public life will 
arise in front of Ukraine. One should hope that the Ukrainian law-making idea in this regard will follow the example of the West and will be preceded by the need for the organization of administrative justice as the only true guarantee of this system".

Analyzing these historical memorial documents, the question naturally arises whether it is ready and if so, then to what extent a modern Ukrainian legal and scientific thought is ready to not only perceive the best experience of subjects of public administration activity, administrative justice, but also to implement and develop progressive achievements of European administrative-legal and administrativeprocedural science and practice.

National history should not only be known and respected, but its achievements must also be used purposefully and consistently. Many answers to questions about administrative jurisdiction, the scope of administrative law, and other disputed topics discussed by the legal community, in fact, were comprehensively substantiated in the 19th and 20th centuries.

\section{Why is it impossible to appeal to administrative court only because you do not like the authorities' decision?}

Administrative justice is an effective instrument for protecting rights violated by public authorities, but it should be properly applied. There are legally provided preconditions where administrative proceedings are being conducted in order to protect human rights.

This does not mean that there may be the cases where administrative proceedings will not work in the event of subjective law violation. Administrative courts are obliged to protect a person, to renew their rights, but unfortunately, plaintiffs are often unaware of the preconditions for appealing to court and do not always understand where there is actually a violation and where there is no. But they look forward to judicial protection, which is impossible, because the underlying preconditions for appeal to an administrative court or satisfaction of claims have not been taken into account. Then the courts must refuse to open the proceedings.

Part 1, Article 2 of the Code of Administrative Legal Proceedings of Ukraine contains preconditions for appeal to the administrative court. 
What must exactly be considered? First of all, there must be publiclegal relations, namely, objectively existing public relations, regulated by the norms of law between the plaintiff and the defendant.

It is not about any legal relations, but only about public-legal (administrative-legal) relations. It is impossible to appeal to an administrative court without them. It is in this fact where the idea of subjective judicial control manifests itself, that is, the court controls what has actually happened.

One of the mandatory preconditions is the existence of a violated right.

For example, a man disputes a council decision, believing that an allocated land plot is insufficient, while the local council has allocated this plot to his wife. The administrative court will refuse the man in satisfaction of his claim, as he was wrong, believing that he has certain rights to this plot.

The list of preconditions for appeal to the administrative court should include the subjects of power authorities. If there are relations, but there is no subject of power authorities, then there is more likely to be no administrative-legal relations. If such legal relations do not have a representative of public authority, administrative courts will not carry out a protective function.

One can often observe when a subject of power authorities exercises not public-powerful, but private powers. For example, we have a law on public procurement. Public procurement is made up of two consecutive legal relations. Number one is competitive relations when the winner is announced and determined. This is, of course, an administrative law, and such legal relations are a common and permanent object of judicial control of administrative courts. The second type of legal relations in public procurement begins from the moment when the winner is determined and an agreement on the provision of services or the purchase of goods is made. These are private-legal relations, which are the subject to court examination in accordance with the rules of the Civil Procedural Code of Ukraine or the Commercial Procedural Code of Ukraine.

A lot of discussions arise about the nature of the Public Council of Good Faith. When people say that this is the subject of power authorities, they refer to clause 9, part 1, Art. 19 of the Code of Administrative Legal Proceedings of Ukraine, according to which disputes concerning the appeal 
of decisions of attestation, competition, medical and social expert commissions and other similar bodies are administrative jurisdiction. The Public Council of Good Faith is referred precisely to "other similar bodies". But the phrase "council of good faith" is preceded by such an adjective as "public". It is immediately apparent that this council belongs to the publicity. Is the publicity a public authority or not? Is this power at all?

However, this is a completely different topic, and at present we are talking about the preconditions for appeals to administrative courts. These preconditions must be taken into account and you will definitely obtain a worthy legal protection.

\section{Public Authority as a Criterion of Administrative Jurisdiction}

There are many manifestations of public authority and they are different, so for a successful appeal to the administrative court with a claim, it is necessary to correctly determine whether there has been a violation of subjective law by a representative of public authority exactly.

The task of administrative courts is to verify the legality and reasonability of any manifestations of public authority having an administrative-legal nature. As a general rule, the jurisdiction of administrative courts does not apply to legal disputes in which there are no subjects of public authority. Almost the only exception to the rule of judicial control of administrative courts under the subjects of authority is administrative and legal relations without the subjects of power authorities, with the participation of only physical persons or legal entities.

First of all, we have to find out what public authority is? It is characterized by the ability to influence the behavior of people by making the appropriate decision, performing activities or reaching the predicted state of public relations. Volitional decision of the representative of public authority extends to people, manifesting in the possession of the material world objects. For example, an order for dismissal from the public service, an administrative act on the disposal of minerals, land plots, monetary assets, property complexes, objects of public property, etc.

Public authority

Public authority is recognized by society, citizens of Ukraine, or a significant part of this population. The publicity of authorities is ensured by binding resolutions, the legal force of which extends to participants in 
public relations. If these resolutions are not carried out voluntarily, then state coercion (criminal, criminal procedure, administrative coercion) is applied to those to whom such will is directed. Therefore, a subject that avoids proper execution of the decision will be forced to execute it, since public authorities are empowered to use state coercion. In particular, the Code of Administrative Legal Proceedings of Ukraine has regulated measures of procedural coercion (Articles 144-149).

The next feature of public authority is that the subjects of public authority are provided with the necessary resources such as financial, material resources, and personnel. Moreover, people hired by public authority at the positions, undergo vocational training and retraining.

We have to include an official nature in the features of public authority. Thus, the Parliament, the Government, the judicial power are recognized by the Constitution, provided by laws, act on the basis of laws, have special external features. For example, the symbols of the judicial power such as the mantle, and the badge are stated in the Law of Ukraine "On the Judicial System and the Status of Judges".

The next feature of public authority is its relative autonomy. The subjects of public authority are separated from each other organizationally.

Therefore, the conclusion whether we deal with a subject of power authority, or with any other subject-holder of private authority, can only be done when we thoroughly analyze the features of public authority. If there is no compulsory, the most approximate set of features of public authority, and only one of the above features is available, one can be misled in determining the nature of one or another participant in disputed legal relations, defining the subject as the implementer of public authority by mistake, and indicating that the public legal relations are present.

In the Code of Administrative Legal Proceedings of Ukraine, representatives of public authority are defined as subjects of power authorities (clause 7, part 1, Art. 4). Taking into account that the concept of "a subject of power authorities" provided by the Code of Administrative Legal Proceedings of Ukraine is not sufficiently perfect and evaluative in its essence, it is sometimes unreasonable to identify this subject with the participants of public relations who are not holders of public authorities. On the contrary, we must clearly understand who such 
subject is, by what power is characterized, when the power is public and in which particular subjects this public authority is personified.

There are several types of subjects of power authorities representatives of public authority. Such authorities are, in particular, state authorities, state bodies (the Security Service of Ukraine, the Central Election Commission, the High Qualifications Commission of Judges of Ukraine, the national commissions in the market of natural monopolies, etc.), the authorities of the Autonomous Republic of Crimea, local selfgovernment bodies (Articles 6, 19, 75, 113, 118, 124, 125 of the Constitution of Ukraine, clause 7, part 1, Art. 4 of the Code of Administrative Legal Proceedings of Ukraine), etc.

A special representative of public power is the National Bank of Ukraine, which, although not in the system of state authorities, state bodies, but in accordance with the Law "On the National Bank of Ukraine" is the central bank of Ukraine, a special central state authority (Article 2). Due to its competence, status and instruments applied to it, the National Bank of Ukraine should be recognized as a public authority, although its main function is to ensure the stability of the monetary unit of Ukraine (Art. 6 of the Law of Ukraine "On the National Bank of Ukraine").

Representatives of public authority are also the Verkhovna Rada of the Autonomous Republic of Crimea, the Council of Ministers of the Autonomous Republic of Crimea, ministries and republican committees, provided by the Constitution of the Autonomous Republic of Crimea.

A representative of public authority is also the local self-government bodies, which are the closest to people, with which a considerable number of administrative disputes appears resolved by administrative courts.

Another specific entity created by the state to carry out its functions is the Deposit Guarantee Fund of Physical Persons. This is the holder of authority, as the state legislatively defined the scope of competence, task and purpose of this Fund, gave it powers to dispose, make decisions at its discretion. Although it is not a state establishment and such Fund is an institution that performs special functions in the field of guaranteeing deposits of individuals and the withdrawal of insolvent banks from the market and liquidation of banks in cases established by this Law (Art. 3, 4 of the Law of Ukraine "On Deposit Guarantee System of individuals"), it is a fully-functional subject of power authorities. 
Conducting state control over property, real estate objects, money does not mean that the state acts as a subject of private law in these cases. Such activity of the state, if it is based on the provisions of administrative legislation with an external manifestation of administrative competence, is always administrative. And in this activity public authority is manifested.

Therefore, all subjects of power authorities personify public authority in Ukraine.

At the same time, it is worth drawing attention to three objective circumstances.

First of all, the list of subjects of authority, indicated in Clause 7, Part 1, Art. 4 of the Code of Administrative Legal Proceedings of Ukraine is not complete, since other entities of authority, not provided by this norm, can enter into administrative-legal relations too. For example, such subjects of power authorities include a military unit, a customs, a border detachment, etc. Therefore, it is obvious that the norms of the Code of Administrative Legal Proceedings of Ukraine, other national legislation determine the organizational legal form, legal status of other subjects of power authorities as well. Such subjects, for example, are the National Commission for Rehabilitation (Clause 13, Part 1, Art. 19 of the CAP of Ukraine), the bodies of state border security of the State Border Security Service of Ukraine (Art. 10 of the Law of Ukraine "On the State Border Security Service of Ukraine").

Secondly, the exercise of public authority functions, in addition to the subjects of power authorities, can be delegated to other entities, in particular, representatives of self-governing professions. The state can delegate its public authorities to self-governing structures, authorized subjects, which will partially perform these functions following the instructions of the state. There are many such authorized subjects which representatives are self-governing professions such as notaries, advocates, insolvency officials, representatives of customs brokers, auditors, etc.

As holders of a certain amount of public authorities, it is necessary to distinguish the organizations of these self-governing professions, which ensure their functioning, control the qualification and discipline, in particular, they are the Audit Chamber of Ukraine, the Notary Chamber of Ukraine, the Qualification-Disciplinary Commission of Advocates, etc.

Thirdly, the subjects of power authorities, exercising the powers provided in the norms of the Civil Code of Ukraine (Articles 2, 167-173), 
are parties to private-legal relations. It is obvious that such relations do not apply to the jurisdiction of administrative courts. The evaluation of both the nature of the law norms and disputed legal relations allows making the correct conclusion at the end, whether the subject of authority exercised public authority and whether this dispute belongs to jurisdiction of the administrative court.

Thus, public power in Ukraine is represented by a multi-branching system of subjects of authority, which differ in organizational-legal form, scope of authority and purpose of activity. Therefore, it is worth suggesting a classification of subjects of authority for a correct and substantiated conclusion about the subject of authority and its differentiation from entities that do not exercise public authorities.

The first group is the subjects of power authorities with the status of a legal entity. These are already mentioned state power bodies, state bodies, the National Bank of Ukraine, public law funds, the authorities of the Autonomous Republic of Crimea, local self-government bodies, etc. However, it should be emphasized that these subjects are so ambiguous. Inside the entity itself, another public authority representative may also be formed, for example, the apparatus or secretariat of the state authority, which will be defined as the legal entity in the regulations. Such representative, for example, is the Staff of the Verkhovna Rada of Ukraine (clauses 1, 5 of the Regulations on the Staff of the Verkhovna Rada of Ukraine). Such organizational entities are full participants in administrative-legal relations, which can be a subject for examination in administrative courts.

The second group is the subjects of power authorities without the status of a legal entity. In order to better understand what this subject is, it is worth referring to clause 9, part 1, Art. 19 of the CAP of Ukraine, dealing with various competition commissions. For example, many administrative cases arise due to the conclusions of attestation commissions, medical and social expert commissions. I should warn that this legislative provision does not mean that any collective entity will necessarily be the subject of power authorities. When it comes to collective entity, it should be examined from the point of view of the nature and external manifestations of public authority.

There are two types of subjects of power authorities without the status of a legal entity: 
- Organizational independent subjects of power authorities without the status of a legal entity, such as medical and social expert commissions;

- Subjects of power authorities without a status of a legal entity that are in the organizational structure of another subject of authority, for example, the Disciplinary Chamber of the High Council for Justice.

The third group is the individual (personified) subjects of power authorities. This is a certain person - an official, a servant of the subject of authorities with the status of a legal entity.

Such subject of power authorities may be the head (except for political positions) of the subject of authorities, representatives of local self-government bodies, who are in positions, representatives of the state service.

Evaluating the classification of subjects of power authorities, attention should be paid to a group of subjects, which, although they are not subjects of authorities, but who are delegated authorities to exercise public authority. Such subjects are self-governing professions, their organizations, acting on the basis, within the limits and in the manner prescribed by administrative law. That is, if a private notary acts in accordance with the provisions of the Law of Ukraine "On the state registration of material rights to immovable property and their encumbrances", it implements administrative competence. The phrase "state registration" indicates the administrative-legal nature of the subject's activity.

Therefore, in order to determine the belonging of legal dispute to the jurisdiction of administrative court correctly, it is necessary to make sure that the representative of public authority takes part in a disputed legal relations, that is, the subject of power authorities of a certain type or the subject of delegated authority (the holder of public authority) determined by law (by legislation) which carries out administrative powers in such legal relations.

\section{Administrative Jurisdiction: Essence, Criteria and Limits}

Although the advanced ideas of administrative justice in Ukraine in fact began to be implemented in 2005, and over the years, the pace of formation and development of this democratic institute only grew, but despite all measures, many theoretical and applied challenges were the essential companions of national administrative justice. The most 
discussed and causing sharp contradictions in the legal community is the subject of administrative jurisdiction, the definition of nature of disputed legal relations, and the differentiation of the court competence as for consideration and resolution of public-legal disputes.

With the beginning of work of the Supreme Court on December 15, 2017, challenges were not overcome, including the justification of administrative jurisdiction content, they were only aggravated, took more extensive dimensions, and in turn, resulted in the negative consequences of their existence.

The same as fifteen years ago, proper scientific justification and verification of practice require the essence, criteria and limits of administrative jurisdiction. We should clarify the nature of administrative jurisdiction and its criteria...

It is essential that awareness, critical perception, research and proper implementation of these criteria will result in correct definition of legal dispute nature, justified appeal to administrative court for the protection of rights, freedoms and interests.

Article 124 of the Constitution of Ukraine stipulates that the jurisdiction of courts extends to any legal dispute. Obviously, such disputes are considered, in particular, by administrative courts in accordance with the Code of Administrative Legal Proceedings of Ukraine. But the fact that legal disputes do not always have an obvious branch nature complicates the consideration and resolution of such disputes. When we talk about legal dispute, we often deal with a rather heterogeneous and uncertain legal phenomenon. And this explains such circumstance that the topic of administrative jurisdiction definition, differentiating it from other jurisdictions - economic, criminal, and civil has been, perhaps, the most disputed, it is so now, and obviously, will last for a long time.

Many legal relations arising in society may have a "mixed" nature; private-public legal relations are widespread. These legal relations arise with the participation of holders of various powers such as civil, economic, administrative, criminal and criminal-procedural, constitutional powers. Relations that we try to relate to a specific court jurisdiction may be regulated by several different legal acts. Relations arise in relation to different objects and for different reasons. All these are: subjects, law 
norms, and the basis for the emergence of these public relations determine the complexity of a specific court jurisdiction definition.

Accordingly, we can not always clearly say whether a dispute belongs to the jurisdiction of an administrative court. But at the same time, national legislation stipulates that under all circumstances and conditions it is necessary to determine where there is an administrative dispute, and, where there is no.

The correct definition of court jurisdiction and the nature (type) of legal relations will directly determine the success, prospects, completeness and effectiveness of the protection of rights of a person, who appeals for protection to the court.

Responsibility for determining the court jurisdiction, justification for referring a particular case to jurisdiction of a particular court is the responsibility of courts themselves. In particular, the Supreme Court should formulate its practice in such a way that society, the participants in legal relations, the parties, and other courts could understand by what criteria (indicators) we could refer one or other disputes to administrative jurisdiction.

Based on a critical analysis of provisions of the administrative-legal relations, Common Administrative Law, national legislation, and conclusions of legal science and methodology, five criteria should be proposed, on the basis of which the disputes can be recognized as appropriate to cases governed by the jurisdiction of administrative courts. The reasonability and effectiveness of criteria of administrative jurisdiction are proved and tested by practice, namely, by the activity of subjects of public administration as well as judicial practice.

We will study the criteria of administrative jurisdiction step-by-step.

\section{The first criterion of administrative jurisdiction is the subject of}

\section{power authorities, present in public relations of disputed nature}

It is necessary to make some remarks as for the subject of authorities as a criterion of administrative jurisdiction.

The first remark concerns the fact that under the civil law the holders of civil rights have civil authorities. They may be participants in private legal relations. If the subject of authority is a party to the purchase and sales agreement, then it is obvious that such relations will not be administrative and legal, and the dispute arising out of such legal relations 
will be considered and resolved according to the rules of the Civil Procedural Code of Ukraine. Only exercise of administrative powers by the subject of power authorities, subject's application of instruments of activity on the basis of these powers (normative acts, administrative acts, and administrative agreements) will cause the formation of administrative-legal relations.

The second remark is that a small number of administrative-legal relations arise without the participation of the subject of power authorities. Judicial practice knows cases related to access to public information, where its administrators may be individuals or legal entities of private law. In such legal relations, one of their participants have the right to the requested information, other public information providers (not necessarily the subjects of authority) bear obligations to distribute such information. This includes, in particular, information on natural environment conditions. Such legal relations can be formed without the participation of the subject of authority.

The concept of the subject of power authorities provided by clause 7 , Art. 4 of the CAP of Ukraine a law-maker has formulated very approximately, only listing those who belong to the subjects of power authorities. This norm mentions that such subjects are state power authorities, local self-government bodies, officials and officers. However, there have been many other holders of public authority that are the subjects of power authorities by nature but they have been left outside the list provided by clause 7, Art. 4 of the CAP of Ukraine. And when the dispute arises and it is necessary to determine whether administrative jurisdiction is present or not, the participants of disputed legal relations such as the court, parties, and advocates can not always say definitely that a certain institution is the subject of authority.

A comprehensive list of subjects of power authorities can be represented by such a universal classification of these subjects:

- Subjects of power authorities having legal status - in particular, state power bodies, state bodies, local self-government bodies, etc.;

- Entities which do not have the status of a legal entity, collective establishments - in particular, attestation, competition, medical and social expert commissions;

- Individual subjects of power authorities - officials and officers of public authorities, state bodies, local self-government bodies. 
The second criterion of administrative jurisdiction is administrative-legal relations (public-legal relations). If we draw attention to some norms of the CAP (in particular, Articles 2, 4, 5, 19), then we will see that a law-maker uses the concept of "legal relations", "relations", "public relations". It is obvious that for the proper functioning and application of administrative justice in Ukraine, it is necessary to ensure that exactly the administrative-legal relations have been formed.

A law-maker put an approximate list of such relations in Art. 19 of the CAP of Ukraine. However, it does not cover all objectively existing and possible administrative-legal relations. But such description does not indicate all existing administrative-legal relations. In general, legal relations are administrative, if they are governed by administrative law. If a conflict arises, one should find a law (normative act) governing these public relations. It is worth keeping in mind that the administrative law norm may be imperative, binding, compulsory, and prohibitive. An example of such norm is, in particular, clause 1 of Art. 11 of the Law of Ukraine "On state registration of property rights to immovable property and their encumbrances" - "The state registrar makes decisions independently based on consideration of applications in the field of state registration of rights".

In addition, the norm is administrative, if it provides for a certain monopoly of a public authority representative for one or another activity, and no alternative is foreseen, but only a certain type of behavior of the subject is determined. For example, the norms of pension law stipulate that for determination, recalculation and establishment of a pension one should apply exclusively to the bodies of the Pension Fund of Ukraine. Typical norms of administrative law, for example, are also the norms of the Tax Code of Ukraine, norms of laws on public service, etc.

As for the administrative-legal relations themselves, first of all, those relations arise from the initiative of physical persons and legal entities that appeal to the subject of power authorities to exercise their rights, freedoms or interests. A person, citizen appeals to the subject of power authorities to exercise the rights guaranteed in Section 2 "Rights, freedoms and duties of a person and a citizen" of the Constitution of Ukraine. Constitutional law is always implemented through an administrative procedure, through the appeal of a person to the subject of authority. This is one of the most widespread types of administrative-legal relations, and the purpose of the state, state bodies in the society is revealed through this type of administrative-legal relations - "A person, 
they life and health, honesty and dignity, inviolability and security are recognized as the highest social value in Ukraine. Human rights and freedoms and their guarantees determine the content and direction of the state activities. The state is responsible to a person for its activities. The basic duty of the state is the assertion and guarantee of human rights and freedoms" (Art. 3 of the Constitution of Ukraine).

The state is called for provision of the rights of a person, citizen and it is in human rights protection by the subjects of power authorities where the purpose of administrative law lies. I emphasize that administrative law is not only about bringing to administrative responsibility, or exercise of government administrative functions, but also the activity of authorized representatives of the state, aimed at creating conditions in which a person can properly exercise their rights provided by the Constitution of Ukraine.

The second type of administrative-legal relations arises according to the will of the subject of power authorities. Due to these relations, intervention procedures are implemented, arising in connection with the necessity of exercising the duties of the subject of power authorities provided by law for it.

For example, the State Service of Ukraine for Emergency Situations organizes and carries out state supervision (control) for observing the requirements of laws and other normative legal acts on the issues of technological and fire safety, civil protection by ministries, other central executive bodies, the Council of Ministers of the Autonomous Republic of Crimea, local state administrations, other state bodies and local selfgovernment bodies, economic entities (clause 39 (4) On Regulation on the State Service of Ukraine for Emergency Situations).

Therefore, inspections by representatives of the Service for Emergency Situations causes the emergence of a second type of administrative-legal relations, namely, relations formed according to the will of this service.

It should be emphasized that the administrative-legal relations that arise according to the will of the subject of power authorities are formed also during tax, financial and other inspections.

Therefore, this type of legal relations - the administrative-legal relations that arise according to the will of the subject of power authorities is formed in connection with implementation by the subject of power authorities of such public administration functions (public-power managerial functions) as forecasting, planning, accounting, organization (formation), control (supervision). 
The third type of administrative-legal relations is relations that arise exclusively with the participation of subjects of power authorities in connection with their interaction. Evaluating this type of legal relations, we must proceed from the assumption that the activity of representatives of the public power itself (state apparatus, the subjects of this apparatus), in addition to other types of their public-legal activity (constitutionallegal, criminal-legal, procedural) is also administrative-legal one. This type of administrative-legal relations arises when two or more of such subjects exchange information mutually realizing their rights and responsibilities to perform their tasks.

Administrative-legal relations arising exclusively with the participation of subjects of authorities due to their interaction should be perceived differentially since external and internal administrative-legal relations of interaction exist objectively.

External administrative-legal relations of interaction are formed when two or more subjects of power authorities interact with each other. For example, within ten days from the date of notification receipt on resolution to be final, a representative body (The representative body - the Ministry of Justice of Ukraine) sends a brief statement of resolution to the Plaintiff, to the Commissioner of the Verkhovna Rada of Ukraine for Human Rights, all state bodies, officials and other entities, directly involved in the case, on which the resolution was made (Article 5 of the Law of Ukraine "On the implementation of resolutions and application of practice of the European Court on Human Rights").

In addition to these external relations there are legal relations, the socalled internal ones. Any body (court, ministry, local executive bodies, local self-government bodies) has internal structural units - the secretariat, the apparatus, departments, etc., which exchange information with each other, prepare draft documents, make draft acts - ensure the full functioning of such body. An example of this type of administrative-legal relations is the relations with the processing of information about taxpayers, when this information is processed within the tax authority itself, and according to the results of such processing and storage of information, tax inspections can be assigned and carried out.

For example, the unit of computerization and accounting of taxpayers on the day of receipt of application in form № 1-OPP and related documents from the authorized person or manager of property transfers them to the taxation division of legal entities for making a conclusion on the expansion of features of tax accounting and taxation specified in 
clause 153.14 of Art. 153 of Section III of the Tax Code of Ukraine (for agreements on joint venture) or sub-clause 153.13.10 clause 153.13 of Art. 153 of section III of the TCU (for property management agreements). The conclusion is signed by the head of the department of legal entities taxation and is provided to the unit of computerization and accounting of taxpayers not later than the next working day from the day of application submission in form № 1-OPP (sub-clause 1.1.1 Order of the State Tax Service of Ukraine "On Approval of the Procedure for Interaction between the Departments of the State Tax Service on the Issues of Registration and Accounting of Taxpayers of 01.08.2012” № 671).

Describing the essence and types of administrative-legal relations, which arise exclusively with the participation of the subjects of power authorities in connection with their interaction, we must definitely pay attention to the fundamental-practical significance of such relations and their types.

It is important to realize the existence of administrative-legal relations that arise exclusively with the participation of the subjects of power authorities in connection with their interaction and to divide them into external and internal legal relations for the following reasons.

First of all, these administrative-legal relations as well as the others are the grounds for appeal to the court. So, Art. 2, 5 of the CAP of Ukraine stipulates that the administrative court resolves disputes in the field of public-legal relations in order to effectively protect the rights, freedoms and interests of physical persons, the rights and interests of legal entities from violations of the subjects of authority.

Secondly, the administrative court will resolve disputes in the field of public-legal relations by a claim of the subject that is a party to such legal relations.

Therefore, the absence of administrative-legal relations (public-legal relations), or the absence of a plaintiff in these relations, makes it impossible to justify the appeal to an administrative court and resolve the dispute. A person who has not been (or is not now) in disputed legal relations can not apply to an administrative court. Therefore, if there are no administrative-legal relations or the subject submitting a claim, has not been in them - as a result, administrative legal proceedings will not be carried out.

Analyzing the second criteria of administrative jurisdiction administrative-legal relations - we should come to the fundamental conclusion - if a person submitted a claim 1) is not a participant of 
administrative-legal relations or 2) appeals against "internal" legal relations - then they subjective rights are not violated. Accordingly, a person has not enough justified actual and legal grounds and can not appeal against resolutions approved within these relations, as well as performed actions, allowed inaction that not in any case extend their legal force on such person, not resulted in legally meaningful outcomes.

The third criterion of administrative jurisdiction is the use of public administration instruments by the subjects of powers authorities.

Any subject of authorities, a representative of public power, acts formally on the basis, within the limits and in the manner provided by law. This way there is its particular instrument. The concept of "instrument" is scientific and theoretical one, but it is used for generalized denotation of all those power manifestations of the subject of authority that may exist.

These are the instruments of activity such as legal acts, administrative acts, administrative agreements, acts of planning, acts of action, and private law instruments of activity, in modern science of administrative law they are now described and systematized. But in legislation, even in the CAP of Ukraine, in practice all these tools are used in full on daily basis.

It is fundamentally for administrative courts to understand the essence, purpose and peculiarities of instruments used by the subjects of authority because they have their peculiarities and can be similar to each other. Legally neutral documents are sometimes "involved" in this list such as information letters, notifications, and certain acts that due to their neutral nature, incapability to cause certain legal outcomes, can not be considered as such instruments.

These legally neutral documents can not be appealed; their appeal is irrational since not all actions, manifestations of the activity of the subject of authority cause certain changes in the rights and duties. However, there are a lot of appeals against such legally neutral documents in the proceedings of administrative courts. And this complicates law enforcement, creates an additional burden on the administrative courts, and, finally, the parties themselves, appealing such legally neutral documents, deviate from their main objective of appealing the very instrument that directly violated their right or freedom.

The fourth criterion of administrative jurisdiction is the field of activity of the subject of power authorities, represented in the form of public administration (or otherwise - a set of certain types of legal 
relations in which the subject of authority, physical person (legal entity) exercises the powers).

In other way public administration can be explained as an administrative procedure, the environment where the subject of authority implements its administrative competence.

We can say that there is facilitating public administration when competences implementation of the subject of authority is caused by the needs of physical person or a legal entity and aimed at these needs to be satisfied as well as at creating conditions for their satisfaction.

Such facilitating public administration can be considered in terms of the activity of the Center of Administrative Services Provision activity. For example, we can exercise out property right to real estate having registered the property.

We exercise the right to freedom of movement outside Ukraine across the world by addressing to the State Migration Service through the administrative procedure for obtaining a passport.

Another domain of the activity manifestation of the subject of power authorities is intervening public administration, caused by initiative of the very subject of authority due to the need to fulfill their duties. For example, such intervening administration is implemented by the police, which, in accordance with the requirements of clause 1, 11, part 1, Art. 23 of the Law of Ukraine "On National Police" carries out preventive activities aimed at preventing offenses, regulates traffic and controls the observance of Road Rules by its participants and the lawfulness of vehicle operation at the street and road network.

The fifth criterion for administrative jurisdiction is that the disputed relations are governed by administrative law norms. It is very quick and easy to make a conclusion whether disputed relations are administrative ones due to availability or absence of such norms.

It is worth noting that normative acts (codes, laws, by-laws) by their nature can be: 1) administrative, 2) have a mixed nature, and contain both norms of administrative law and norms private law.

Thus, the Law of Ukraine "On state registration of property rights to immovable property and their encumbrances" contains the norms of administrative law - clear instructions, provisions which any participant of public relations, physical person and legal entity, willing to register real estate, must obey. In particular, when submitting an application for state registration of rights, the applicant is obliged to inform the state registrar about the existence of property rights encumbrances on real estate 
established by law (part 7, Art. 18 of the Law of Ukraine "On state registration of property rights to immovable property and their encumbrances").

However, a normative act containing both the norms of administrative law and the norms of private (civil) law is the Land Code of Ukraine, where, in particular, land use planning is governed by administrative law (art. 177-180), and the right of ownership to a land plot is regulated by the norms of civil law (Art. 78-91).

Completing the analysis of such criteria, one should emphasize that the conclusion on the belonging of a legal dispute to administrative jurisdiction can be made only when the content of this dispute all five criteria mentioned above are present:

1) The subject of power authorities;

2) Administrative-legal relations;

3) The use of public administration activity instruments by public authorities;

4) The domain of activity of the subject of power authorities, presented in the form of public administration;

5) Disputed relations are regulated by the administrative law norms taking into account the remarks in relation to peculiarities of the subjects of authority and administrative-legal relations.

If at least one of these criteria is missing, we can definitely make a conclusion that there is no administrative jurisdiction.

\section{Information about the author: Bevzenko V. M. Doctor of Law,} Professor at the Department of Administrative Law, Judge of Administrative Court of Cassation of the Supreme Court of Ukraine 